\title{
KEMAMPUAN MENULIS TEKS ANEKDOT DENGAN MENGGUNAKAN MEDIA GAMBAR OLEH SISWA KELAS X SMK SWASTA YPIS MAJU BINJAI TAHUN PELAJARAN 2019/2020
}

\author{
Sudarman Gulo ${ }^{1}$, M. Ali Sidiqin, M.Pd ${ }^{2}$
}

\begin{abstract}
ABSTRAK
Pembelajaran bahasa Indonesia merupakan mata pelajaran terpenting di sekolah. Fokus pembelajaran ini adalah memusatkan agar terwujudnya keterampilan berbahasa. Keterampilan berbahasa mencakup empat aspek yaitu menyimak, membaca, menulis dan berbicara. Keterampilan menulis ialah bagian kegiatan bahasa yang berupa tulis menulis dalam rangka menyampaikan atau mengungkapkan gagasan terhadap pembaca . Menurut Kamus Besar Bahasa Indonesia (KBBI) teks anekdot adalah cerita singkat yang menarik karena lucu dan mengesankan, biasanya mengenai orang penting atau terkenal dan berdasarkan kejadian yang sebenarny. Ada tujuan dalam penelitian ini yaitu untuk mengetahui Kemampuan Siswa Dalam menulis Teks Andekdot dengan menggunakan Media Gambar Oleh Siswa Kelas X SMK YPIS Maju Tahun Pelajaran 2019/2020”. Metode dalam penelitian ini adalah kuantitatif deskriptip, dengan jumlah populasi 108 siswa dan yang menjadi sampel dalam penelitian ini 21 siswa kelas X . Berdasarkan pembahasan di atas dapat dilihat bahwa kemampuan sisiwa dalam menulis teks anekdot dengan mengunakan gambar adalah dengan kategori baik dengan nilai rata rata 82.14. Hal ini dapat dilihat dari perhitungan rata rata nilai yang diperoleh siswa menunjukkan rata rata yang dipeoleh adalah 82,14, Siswa yang memperoleh nilai sangat baik 92-100 berjumlah 1 siswa dengan persentase $4,77 \%$, Siswa yang memperoleh nilai baik 83-92 berjumlah 11 siswa dengan persentase 52,38\%, Siswa yang memperoleh nilai cukup 75-83 berjumlah 7 siswa dengan persentase $33.33 \%$, Siswa yang memperoleh nilai kurang dari 75 berjumlah 2 siswa dengan persentase $9,52 \%$

Dengan mengetahui hasil pengolahan data dalam menentukan kemampuan siswa dalam menulis teks anekdot oleh siswa kelas X TBSM dengan menggunakan media gambar tahun pembelajaran 2019/2020 dengan kategori cukup dengan nilai rata rata 82, 14.
\end{abstract}

Kata Kunci : Kemampuan, Menulis, Teks Anedkdot ,Media Gambar, 


\section{Jurnal Serunai Bahasa Indonesia \\ Vol 17, No. 1, Maret 2020 \\ e-ISSN 2621-5616}

\section{PENDAHULUAN}

Keterampilan berbahasa menyangkut empat komponen, yaitu: a).ketrampilan menyimak (listening skills), b)keterampilan berbicara (speaking skills), c)ketrampilan membaca (reading skills) d) keterampilan menulis (writing skills). Setiap keterampilan ini erat pula berhubungan dengan proses-proses yang mendasari bahasa. Bahasa seseorang mencerminkan pikirannya, semakin trampil seseorang berbahasa, semakin cerah dan jelas pula jalan pikirnya. Menurut Tarigan keterampilan hanya dapat diperoleh dan dikuasai dengan praktik dan banyak latihan. Melatih keterampilan berbahasa berarti melatih ketrampilan berpikir ".

Kurikulum 2013 merupakan kurikulum hasil pengembangan dari kurikulum sebelumnya yaitu kurikulum KTSP 2006. Pada tahun 2013, Kurikulum 2013 mulai diterapkan dibeberapa sekolah di Indonesia. Salah satu hal yang menarik dari penerapan kurikulum 2013 ini adalah materi pembelajarannya. Berbagai jenis teks dengan tujuan sosial, struktur, dan ciri bahasa dipelajari pada kurikulum 2013. Salah satunya adalah teks anekdot, teks anekdot dalam pembelajaran bahasa Indonesia di kelas $\mathrm{X}$ bertujuan untuk melatih siswa berpikir kritis dan kreatif dalam menyelesaikan permasalahan dalam kehidupan nyata dengan cara yang unik dan lebih berperan aktif selama kegiatan pembelajaran. Elain dari segi materi, Kurikulum 2013 menuntut siswa untuk lebih berperan aktif, kreatif dan inovatif selama kegiatan pembelajaran. Kurikulum 2013 juga menggunakan pendekatan saintifik dimana guru lebih mendorong siswa untuk aktif selama pembelajaran berlangsung.
Pembelajaran bahasa Indonesia merupakan mata pelajaran terpenting di sekolah. Fokus pembelajaran ini adalah memusatkan agar terwujudnya keterampilan berbahasa. Keterampilan berbahasa mencakup empat aspek yaitu menyimak, membaca, menulis dan berbicara. Keempat keterampilan tersebut sering diperhatikan dalam pengajaran Bahasa Indonesia dan tidak dapat dipisahkan satu dengan yang lainnya, karena untuk mencapai keterampilan berbahasa yang sempurna, keempat keterampilan tersebut saling berkaitan.

Henry Guntur Tarigan, menyatakan bahwa: "ada empat aspek keterampilan berbahasa yang harus dikuasai oleh para siswa di seluruh Indonesia dan dalam kurikulum sekolah agar dapat memiliki kehidupan yang layak di masa depan, yaitu menyimak, berbicara, membaca, serta menulis."

Jadi, semakin banyak seseorang menyimak, berbicara, dan membaca semakin banyak pula informasi yang diterimanya untuk dapat menghasilkan suatu karya tulis, baik karya sastra maupun karya non sastra. Seiring dengan pendapat tersebut, Henry Guntur Tarigan, mengatakan pula bahwa "menulis merupakan suatu keterampilan berbahasa yang dipergunakan untuk berkomunikasi secara tidak langsung, tidak secara tatap muka dengan orang lain dan merupakan kegiatan yang produktif dan ekspresif." Maka, dengan menguasai keterampilan menulis, diharapkan siswa dapat mengungkapkan gagasan, pikiran, dan perasaan yang dimilikinya setelah menjalani proses pembelajaran dalam berbagai jenis tulisan, khususnya dalam menulis prosa cerita fabel.

Kemampuan berbahasa yang harus dimiliki oleh siswa ialah kemampuan menulis. Menulis merupakan suatu keterampilan berbahasa yang paling akhir setelah 


\section{Jurnal Serunai Bahasa Indonesia \\ Vol 17, No. 1, Maret 2020 \\ e-ISSN 2621-5616}

kemampuan menyimak, berbicara, dan membaca. Keterampilan menulis sangat diperlukan untuk menunjang pengajaran lainnya, khususnya pengajaran bahasa Indonesia. Berdasarkan hal tersebut, apabila seseorang akan menulis sebuah karangan, maka orang tersebut haruslah meng- uasai keempat keterampilan berbahasa tersebut.

Djuhari Suherli, menambahkan bahwa "kegiatan menulis merupakan suatu kegiatan yang oleh sebagian orang dianggap sukar." Kita ketahui bahwa ada orang yang dapat mengomunikasikan gagasannya hanya dengan cara menulis, namun ada pula orang yang dapat mengungkapkannya dengan cara berbicara sesuai dengan keterampilan berbahasa yang dimiliki seseorang.

Pernyataan di atas diperjelas kembali oleh Djuhari Suherli, bahwa "kegiatan menulis merupakan suatu keterampilan yang dapat dibina dan dilatihkan. Kegiatan ini memerlukan latihan dan kebiasaan yang sungguh-sungguh, sehingga kegiatan yang sulit ini dapat diwujudkan. Artinya, dengan latihan setiap orang dapat mengungkapkan gagasannya melalui menulis."

Seiring dengan pendapat di atas, Alwasilah Chaedar, berpendapat bahwa "kemampuan menulis dapat dikembangkan melalui latihan. Latihan ini bisa dikembangkan dalam pembelajaran di sekolah. Dengan praktik menulis, kita akan tahu kesulitan apa yang kita rasakan pada saat menulis. Dari kesulitan tersebut, kita akan mencari tahu cara yang harus diambil dalam menangani kesulitan tersebut."

Henry Guntur Tarigan, mengungkapkan bahwa penyebab kurangnya kemampuan siswa dalam menulis sebagai berikut.

1) Sikap sebagian besar masyarakat terhadap bahasa Indonesia belum menggembirakan, mereka tidak malu memakai bahsa yang salah.

2) Kesibukan guru bahasa Indonesia di luar jam kerjanya menyebabkan mereka tidak sempat lagi memikirkan bagaimana cara pelaksanaan pembelajaran mengarang yang lebih menarik dan efektif.

3) Metode dan teknik mengarang kurang bervariasi serta mungkin sekali hasil karangan siswa yang ada pun tidak dikoreksi.

4) Bagi siswa sendiri pelajaran mengarang dirasakan sebagai beban belaka dan kurang menarik.

5) Latihan mengarang sangat kurang dilakukan oleh siswa.

Pembelajaran menulis teks anekdot pada peserta didik di SMP menunjukkan hasil yang kurang memuaskan. Hal ini disebabkan oleh rendahnya keterampilan menulis siswa dalam pembelajaran menulis teks anekdot, siswa juga kurang menguasai struktur teks anekdot. Oleh karena itu, sebagai upaya untuk mengatasi permasalahan tersebut adalah menghadirkan model pembelajaran Example. Model ini bertujuan mendorong siswa untuk belajar berpikir kritis dengan memecahkan permasalahan-permasalahan yang termuat dalam contoh-contoh gambar yang disajikan. Dengan demikian, model ini menekankan pada konteks analisis siswa.

Menurut Miftahul Huda, "Model Example Non-Example dapat ditujukan untuk mengajar siswa dalam belajar memahami dan menganalisis sebuah konsep. Konsep pada umumnya dipelajari melalui dua cara: pengamatan dan definisi. Example adalah model pembelajaran yang dapat digunakan untuk mengajarkan definisi konsep."

Penelitian ini dilaksanakan di SMK Swasta YPIS Maju sebagai sasaran penelitian, karena sekolah ini merupakan salah satu 
sekolah swasta yang sudah menggunakan dan menerapkan Kurikulum 2013 di sekolah menengah kejuruan di kota Binjai. Berdasarkan hasil observasi peneliti dengan guru bahasa Indonesia dan kepala sekolah di SMK Swasta YPIS Maju, masih banyak ditemukan rendah dan minimnya minar belajar siswa dalam menulis khususnya teks anekdot. Sehingga siswa beranggapan bahwa mereka tidak biasa membuat lelucon, kurangnya ide dan kosa kata dalam menulis teks anekdot, kami lebih suka membaca dari pada menulis teks anekdot. Siswa juga sulit menentukan tema dalam menulis teks anekdot sehingga mereka sulit untuk memulai menulis berawal dari mana

\section{TINJAUAN PUSTAKA}

\section{Pembelajaran Bahasa Indonesia}

Pada hakekatnya pembelajaran merupakan proses komunikasi antar peserta didik dan pendidik serta antarr peserta didik. Menurut Suparmo dalam Abdul Haris tujuan pembelajaran ini akan tercapai apabila dengan pembelajaran efektif yang memudahkan siswa untuk mempelajari sesuatu yang bermanfaat seperti fakta, ketrampilan, nilai konsep dan bagaimana hidup serasi dengan sesame, atau suatu hasil belajar ".

\section{Pengertian Menulis}

Marhiyanto mengatakan, "keterampilan menulis ialah bagian kegiatan bahasa yang berupa tulis menulis dalam rangka menyampaikan atau mengungkapkan gagasan terhadap pembaca." Menulis merupakan salah satu dari empat keterampilan berbahasa yaitu mendengarkan, berbicara, membaca, dan menulis itu sendiri. Setiap keterampilan mempunyai hubungan yang sangat erat dengan keterampilan lainnya dalam memperoleh keterampilan berbahasa. Berikut ini akan dipaparkan mengenai hakikat menulis dan manfaat menulis.

\section{Hakikat Menulis}

Menulis adalah kegiatan yang dilakukan seseorang untuk menghasilkan tulisan. Orang yang melakukan coret mencoret di tembok itu juga bisa dikatakan dia sedang menulis, dengan atau tanpa maksud dan perangkat tertentu. Namun demikian, Widyamartaya dan Sudiati menyatakan bahwa, "menulis adalah keseluruhan rangkaian kegiatan seseorang mengungkapkan gagasan dan menyampaikannya melalui bahasa tulis kepada pembaca untuk dipahami" Dapat dikatakan bahwa menulis adalah proses pembingkisan gagasan oleh seseorang kepada orang lain.

Menulis arti pertamanya adalah membuat huruf, angka, nama, dan sesuatu tanda kebahasaan apa pun dengan sesuatu alat tulis pada suatu halaman tertentu. Kini dalam pengertian yang luas, Gie mengatakan, "menulis merupakan segenap rangkaian kegiatan seseorang mengungkapkan gagasan dan menyampaikannya melalui bahasa tulis kepada masyarakat pembaca untuk dipahami."

Menurut Tarigan, "menulis ialah menurunkan atau melukiskan lambing-lambang grafik yang menggambarkan suatu bahasa yang dipahami oleh seseorang, sehingga orang-orang lain dapat membaca lambang-lambang grafik itu." Gambar atau lukisan mungkin dapat menyampaikan makna-makna, tetapi tidak menggambarkan kesatuan-kesatuan bahasa. Menulis merupakan suatu representasi bagian dari kesatuan-kesatuan ekspresi bahasa. Konsep tersebut memaparkan bahwa menulis merupakan komunikasi tidak langsung yang berupa pemindahan pikiran atau perasaan 
dengan memanfaatkan lambang-lambang grafik sehingga dapat dibaca seperti apa yang diwakili oleh lambang-lambang tersebut. Dengan kata lain, menulis merupakan proses kreatif melahirkan pikiran atau perasaan menjadi tulisan dengan menggunakan bahasa yang dipahami, sehingga orang lain dapat memahami maksud tulisan.Sutarno menyatakan bahwa, "menulis pada dasarnya adalah salah satu bentuk komunikasi antara penulis dengan orang lain (pembaca). Komunikasi dilakukan untuk menyampaikan pesan (messages) melalui media tulis." Pesan yang dimaksudkan di dalam sebuah tulisan dapat diartikan sebagai nilai, norma, dan wacana. Sejalan dengan hal di atas, Nurudin, "menulis adalah segenap rangkaian kegiatan seseorang dalam rangka mengungkapkan gagasan dan menyampaikannya melalui bahasa tulis kepada orang lain agar mudah dipahami." Definisi tersebut mengungkapkan bahwa menulis yang baik adalah menulis yang bisa dipahami oleh orang lain. Berdasarkan pendapat para ahli tersebut, dapat disimpulkan bahwa menulis merupakan rangkaian kegiatan yang dilakukan oleh seseorang dalam hal pengungkapan pikiran, perasaan, ide maupun gagasan ke dalam bahasa tulis atau tulisan kepada orang lain atau pembaca.

\section{Manfaat Menulis}

Pada dasarnya, manfaat utama tulisan adalah sebagai alat komunikasi secara tidak langsung. Menulis sangat penting bagi dunia pendidikan karena memudahkan para pelajar berpikir secara kritis, menikmati dan merasakan hubungan-hubungan, memperdalam daya tanggap atau persepsi, memecahkan masalahmasalah, dan juga menyusun urutan bagi pengalaman. Tulisan dapat membantu menjelaskan pikiran-pikiran. Tidak jarang seseorang menemui apa yang sebenarnya dirasakan dan pikirkan mengenai orang-orang, gagasan gagasan, masalah-masalah, dan kejadan-kejadian hanya dalam proses menulis yang aktual. Dalam buku The Power of Creative Writing "Percy dalam Nurudin pernah mengemukakan beberapa manfaat menulis antara lain:"

1. Sarana untuk Mengungkapkan Diri (A Tool For Self Expression)

Yang dimaksud dengan sarana untuk mengungkapkan diri di sini adalah bahwa dengan menulis, kita dapat mengungkapkan perasaan hati (kegelisahan, keinginan, kemarahan, dan lain-lain). Jadi menulis dapat dijadikan alat untuk menyalurkan uneg-uneg (perasaan hati). Bisa jadi perasaan seseorang tersebut tidak mampu atau tidak bisa diungkapkan dalam lisan, maka menulis menjadi salah satu sarannya.

2. Sarana untuk Pemahaman (A Tool For Understanding)

Menulis bisa mengikat kuat suatu ilmu pengetahuan ke dalam otak. Menulis sebenarnya menancapkan pemahaman kuat dalam otak seseorang. Dengan kata lain, menulis untuk pemahaman. Aktivitas membaca disertai dengan menuliskannya akan mendatangkan kemanfaatan yang lebih besar kaitannya dengan pemahaman daripada aktivitas membaca saja.

3. Membantu Mengembangkan Kepuasan Pribadi, Kebanggaan, Perasaan Harga Diri ( $A$ Tool To Help Developing Personal Satisfaction, Pride, A Feeling Of Self Worth). Menulis bisa meningkatkan kepercayaan akan keterampilan 


\section{Jurnal Serunai Bahasa Indonesia \\ Vol 17, No. 1, Maret 2020 \\ e-ISSN 2621-5616}

diri. Seseorang percaya diri bahwa sebenarnya mempunyai keterampilan terpendam yang belum diberdayakan.

4. Meningkatkan Kesadaran dan Penyerapan Terhadap Lingkungan (A Tool For Increasing Awareness And Perception Of Enviroment). Orang yang menulis itu selalu dituntut untuk terus belajar. Jangka panjangnya tidak hanya peka bahwa ada banyak persoalan sosial yang bisa menjadi bahan untuk ditulis, tetapi juga peka untuk mengembangkan sikap peduli dengan orang lain yang menderita. Menulis akan membisaakan diri menjadi manusia kreatif, inovatif, dan peduli pada masalah-masalah lingkungan.

5. Keterlibatan Secara Bersemangat dan Bukannya Penerimaan yang Pasrah (A Tool For Active Involvement, Not Passive Acceptance). Seorang adalah seorang pencipta. Dengan kata lain, ia adalah manusia kreatif. Jika ada sesuatu yang menurut dia tidak baik atau kurang pas, dia akan terpanggil untuk mengomentari lewat tulisan-tulisannya.

6. Mengembangkan Suatu Pemahaman Tentang dan Keterampilan Menggunakan Bahasa (A Tool For Developing An Understanding Of And Ability To Use The Language). Seseorang menulis tidak asal tulis. Ia harus punya alat yakni bahasa. Seseorang yang ingin menulis harus menguasai bahasa yang dijadikan alat untuk menulis tersebut. Dengan demikian, tanpa mempunyai bahasa yang memadai adalah omong kosong. Kalaupun ia memaksakan diri, hasil dari tulisannya biasanya tidak maksimal.

Dari beberapa manfaat yang telah dipaparkan di atas, maka dapat disimpulkan bahwa dengan menulis seseorang dapat mengekspresikan diri baik dari segi gagasan maupun perasaan yang tengah dirasakan.
Seiring bertambahnya kualitas seseorang dalam menulis, khususnya pemahaman dan penguasaan tentang suatu hal, maka akan meningkat pula kepercayaan diri dalam meulis. Kegiatan menulis tidak hanya berguna bagi seseorang yang menulisnya, tetapi bagi orang lain juga yang membacanya.

\section{Tahapan Menulis}

Dalam proses menulis ada empat tahap yang harus dilalui oleh seorang penulis. Tahaptahap itu sebagai berikut.

1. Tahap pramenulis (prewriting).

Kegiatan pramenulis meliputi segala sesuatu yang terjadi sebelum proses penulisan. Kegiatan penulis dalam pramenulis meliputi: a)Menggali ide. Penggalian ide dapat dilakukan dengan berbagai cara, misalnya dengan banyak membaca literatur, berdiskusi dengan orang lain, atau menggali informasi lewat internet b)Mengingat dan memunculkan ide. Dari menggali ide, hendaknya segera melakukan kegiatan memunculkan ide, misalnya dengan mengajukan beberapa pertanyaan terhadap apa yang telah dibaca. Ide tulisan dapat digunakan sebagai pedoman pramenulis c).Menghubunghubungkan ide. Pengalaman menulis terjadi ketika anda berbicara dan mendengarkan (selama diskusi, menulis bagian-bagian untuk dibaca sendiri, brainstroming, dan sejenisnya)

2. Draft/Buram (Drafting)

Menyusun buram merupakan usaha mengkreasi/mengonstruksi teks secara utuh dan merupakan pengalaman spontan dalam memproduksi wacana. Selama menyusun buram, penulis mencoba untuk tidak ragu-ragu lagi dalam menerapkan tanda baca dan ejaan, menyadari bahwa teks yang disusun akan diperbaiki lagi, diubah, dan disusun ulang.

3. Revisi (Revising)

Merevisi merupakan kesempatan untuk 
berpikir kembali dan mengkonstruksi kembali teks yang telah disusun. Revisi merupakan aktivitas yang berlangsung terus menerus. Penulis perlu terus membaca hasil tulisannya setiap ada kesempatan untuk mengetahui kesalahan dan kelengkapan hasil tulisannya.

\section{Publikasi (Publishing)}

Kegiatan ini dilakukan secara tukar pikiran dalam rangka memperoleh masukan terhadap teks buram yang telah disusun. Masukan dapat diperoleh dari teman sendiri dalam kelompok kecil, dari guru, khalayak dengan memajang pada mading atau dimuat di majalah sekolah.

Tidak jauh berbeda dari Imron Rosidi, Sayuti menyatakan bahwa menulis memiliki tahapan- tahapan sebagai berikut.

a. Tahap pramenulis, pada tahap ini kita harus menggali ide, memilih ide, menyiapkan bahan tulisan.

b. Tahap menulis draf, adalah tahap menulis ideide mereka ke dalam bentuk tulisan yang kasar sebelum dituliskan dalam bentuk tulisan yang sudah jadi.

c. Tahap revisi, adalah tahap memperbaiki ulang atau menambahkan ide- ide baru terhadap karya.

d. Tahap penyunting, pada tahap ini kita harus memperbaiki karangan pada aspek kebahasaan dan kesalahan mekanik yang lain.

e. Tahap publikasi, tulisan akan berarti dan bermanfaat jika dibaca orang lain.

\section{Fungsi Menulis}

Nurgiyantoro mengemukakan, "kegiatan menulis memiliki banyak fungsi bagi para pelakunya. Aktifitas menulis merupakan suatu bentuk manifestasi kompetensi berbahasa paling akhir dikuasai pembelajar bahasa setelah kompetensi mendengarkan, berbicara, dan membaca." Darmadi, menyebutkan ada 7 (tujuh) fungsi menulis yaitu:

a. kegiatan menulis adalah suatu sarana untuk menemukan sesuatu;

b. kegiatan menulis dapat menemukan ide baru;

c. kegiatan menulis dapat melatih, mengorganisasikan, dan menjernihkan berbagai konsep yang kita miliki;

d. kegiatan menulis dapat membantu diri kita untuk menyerap dan memproses informasi;

e. kegiatan menulis dapat melatih sikap objektif yang ada pada diri seseorang;

f. kegiatan menulis akan melatih kita untuk memecahkan beberapa masalah.

g. kegiatan menulis dalam sebuah bidang ilmu akan memungkinkan kita untuk menjadi aktif dan tidak hanya menjadi penerima informasi.

Menurut Henry Guntur Tarigan, fungsi menulis sebagai "alat komunikasi yang tidak langsung." ${ }^{4}$ Sedangkan Darmadi Kaswan, berpendapat bahwa fungsi menulis di antaranya adalah: 1) peningkatan kecerdasan, 2) pengembangan daya inisiatif dan kreatif, 3 ) penumbuhan keberanian, dan 4) pendorongan kemauan dan kemampuan mengumpulkan informasi.

Menurut Enre, fungsi menulis adalah sebagai berikut.

1. Menulis menolong kita menemukan kembali apa yang pernah kita ketahui.

2. Menulis menghasilkan ide-ide baru. Tindakan menulis merangsang pikiran kita untuk mengadakan hubungan, mencari pertalian, dan menarik perasaan (analogi) 
yang tidak akan pernah terjadi seandainya kita tidak mulai menulis.

3. Menulis membantu mengorganisasikan pikiran kita, dan menempatkannya dalam suatu bentuk yang berdiri sendiri.

4. Menulis menjadikan pikiran seseorang siap untuk dilihat dan dievaluasi.

5. Menulis membantu kita menyerap dan menguasai informasi baru.

6. Menulis membantu kita memecahkan masalah dengan jalan memperjelas unsur-unsurnya dan menempatkannya dalam suatu konteks visual, sehingga ia dapat diuji.

Dari pendapat beberapa ahli di atas, dapat disimpulkan bahwa fungsi menulis selain sebagai alat komunikasi tidak langsung, menulis juga berfungsi sebagai alat pengembangan kecerdasan dan alat untuk menghasilkan ide-ide baru. Seseorang dapat dikatakan telah mampu menulis dengan baik, jika dia dapat mengungkapkan maksudnya dengan jelas sehingga orang lain dapat memahami apa yang diungkapkannya.

Menurut Henry Guntur Tarigan, ciri-ciri tulisan yang baik adalah sebagai berikut.

1. Tulisan yang baik mencerminkan kemampuan menulis mempergunakan nada yang serasi

2. Tulisan yang baik mencerminkan kemampuan penulis menyusun bahan- bahan yang tersedia menjadi suatu keseluruhan yang utuh.

3. Tulisan yang baik mencerminkan kemampuan penulis untuk menulis dengan jelas dan tidak samar-samar: memanfaatkan struktur kalimat, bahasa, dan contoh-contoh sehingga maknanya sesuai dengan yang diinginkan oleh penulis. Dengan demikian, para pembaca tidak susah payah memahami makna yang tersurat dan tersirat.

4. Tulisan yang baik mencerminkan kemampuan penulis untuk menulis secara meyakinkan.

5. Tulisan yang baik mencerminkan kemampuan penulis untuk mengkritik naskah tulisannya yang pertama serta memperbaikinya.

6. Tulisan yang baik mencerminkan kebanggaan penulis dalam naskah atau manuskrip. Kesudian mempergunakan ejaan dan tanda baca secara seksama, memeriksa makna kata, dan hubungan ketatabahasaan dalam kalimat-kalimat sebelum menyajikan kepada para pembaca.

\section{Hakekat Teks Anekdot}

Mahsun mengemukakan teks adalah "satuan bahasa yang digunakan sebagai ungkapan suatu kegiatan sosial, baik secara lisan maupun tulis dengan struktur berpikir yang lengkap"5. Selain itu, karena teks digunakan untuk pernyataan suatu kegiatan sosial dengan struktur berpikir yang lengkap, maka setiap teks memiliki struktur tersendiri. Sementara, tujuan sosial yang akan dicapai setiap manusia beragam, maka akan muncul beragam jenis teks dengan struktur teks atau struktur berpikirnya.

Menurut Kamus Besar Bahasa Indonesia (KBBI) menyatakan bahwa, "anekdot adalah cerita singkat yang menarik karena lucu dan mengesankan, biasanya mengenai orang penting atau terkenal dan berdasarkan kejadian yang sebenarnya"6. Pada buku siswa (wajib) yang berjudul bahasa Indonesia ekspresi diri 


\section{Jurnal Serunai Bahasa Indonesia \\ Vol 17, No. 1, Maret 2020 \\ e-ISSN 2621-5616}

dan Akademik, anekdot ialah cerita singkat yang menarik karena lucu dan mengesankan, biasanya mengenai orang penting atau terkenal dan berdasarkan kejadian yang sebenarnya.

Selain itu, anekdot merupakan cerita rekaan yang tidak harus didasarkan pada kenyataan yang terjadi di masyarakat, partisipan atau pelaku di dalamnya pun tidak harus orang penting. Teks anekdot juga berisi peristiwa yang membuat perasaan jengkel atau konyol, dimana perasaan tersebut merupakan krisis yang ditanggapi dengan reaksi dari pertentangan antara nyaman dan tidak nyaman, puas dan frustasi, serta tercapai dan gagal.

Anekdot merupakan salah satu genre sastra yang biasanya untuk merefleksikan diri maupun isu-isu yang tengah hangat dan menjadi fenomena di lingkungan kehidupan bermasyarakat. Menurut Mahsun, "teks anekdot merupakan genre sastra yang termasuk dalam jenis teks tunggal. Slade mengemukakan bahwa anekdot itu terdiri dari abstrak-orientasi-krisisreaksi-koda". Berkaitan dengan penulisan teks anekdot, ada dua hal yang harus dipahami oleh guru, yaitu:

\section{a. Tujuan Komunikatif}

Jenis teks ini sangat efektif untuk mengemas informasi yang berupa cerita tentang suatu kejadian konyol di masa lalu. Hal ini dimaksudkan untuk mengajak para pembaca berbagi emosi. Karena bersifat konyol, pada dasarnya anekdot memiliki karakter lucu.

b. Struktur Retorik

Anekdot memiliki elemen teks yang disusun secara retorik: judul-abstrak-orientasi-krisisreaksi-koda. Berikut penjelasan mengenai unsur-unsur struktur retorik anekdot menurut Pardiyono
1. Judul berbentuk frase yang berisi satu topik kejadian di masa lalu untuk dibagikan dengan para pembaca.

2. Abstrak sangat umum berupa suatu pernyataan retorik atau pernyataan yang berupa eklamasi. Bagian abstrak adalah bagian yang bisa menentukan apakah para pembaca tertarik secara emosional untuk melakukan tukar pendapat.

3. Orientasi berisi pengantar cerita, atau latar cerita.

4. Krisis berisi pemaparan kejadian puncak atau insiden yang merupakan inti dari kekonyolan cerita atau kekonyolan kejadian.

5. Reaksi berisi reaksi atau tindakan solusi yang diambil atau dilakukan oleh penulis untuk mengatasi atau menyelamatkan diri dari insiden tersebut.

6. Koda adalah penutup cerita yang merupakan akhir atas insiden tersebut.

7. Kaidah Kebahasaan

Teks anekdot banyak mempergunakan kalimat deklaratif dan pernyataan kausal pada bagian abstrak. Penggunaan bentuk lampau sangat dominan karena anekdot berisi suatu paparan cerita atau kejadian konyol di masa lalu.Penggunaan konjungsi sudah pasti diperlukan untuk menunjukkan urutan kejadian.Berikut uraian mengenai ciri kebahasaan dalam teks anekdot.

a. Teks anekdot menggunakan kalimat deklaratif

Chaer danAgustina menyatakan bahwa, kalimat deklaratif adalah kalimat yang isinya hanya meminta pendengar atau yang mendengar kalimat itu untuk menaruh perhatian saja, tidak usah melakukan apa-apa, sebab maksud si pengujar hanya untuk memberitahukan saja. Austin (melalui Chaer \& Agustina) membedakan kalimat deklaratif 
berdasarkan maknanya menjadi kalimat konstatif dan kalimat performatif.

Kalimat konstatif adalah kalimat yang berisi pernyataan belaka, sedangkan kalimat performatif adalah kalimat yang berisi perlakuan.

1. Teks anekdot menggunakan pernyataan kausal

2. Teks anekdot menggunakan bentuk kalimat lampau

3. Teks anekdot menggunakan konjungsi

Konjungsi adalah kata atau gabungan kata yang berfungsi menghubungkan bagian ujaran yang mungkin berupa kata dengan kata, frase dengan frase, klausa dengan klausa, maupun kalimat dengan kalimat. Chaer mengatakan, "umpamanya kata-kata dan, sedangkan, dan meskipun pada kalimat-kalimat berikut adalah sebuah konjungsi”.

1). Kami berjuang untuk nusa dan bangsa.

2). Tamu sudah banyak yang datang sedangkan beliau belum muncul juga.

3). Meskipun kami melarat, kami tidak mau melakukan pekerjaan itu.

Ada dua macam konjungsi yaitu konjungsi intrakalimat dan konjungsi antarkalimat. Konjungsi intrakalimat berfungsi menghubungkan kata dengan kata, frase dengan frase, atau klausa dengan klausa yang berada di dalam sebuah kalimat. Menurut Chaer, "konjungsi antarkalimat adalah kata atau gabungan kata yang menghubungkan kalimat dengan kalimat atau paragraf dengan paragraf berikutnya".

\section{Pengertian Media Pembelajaran}

Secara umum media dapat dipahami sebagai perantara dari suatu informasi yang berasal dari sumber informasi untuk diterima oleh penerima.
Informasi tersebut dapat berupa apapun, baik yang bermuatan pendidikan, politik, teknologi, maupun informasi atau yang bisa disebut dengan berita. Menurut sumiatidan Asra ,"Media pembelajaran dapat daiartikan sebagai segala sesuatu yang dapat digumnakan untuk menyalurkan pesan,(masage), merangsang pemikiran,perasaan, perhatian dan kemauan siswa sehingga dapat mendorong proses belajar". Sedangkan Menurut Sukiman "Yang dimaksud media pembelajaran adalah segala sesuatu yang dapat digunakan untuk menyalurkan pesan, dari pengirim ke penerima sehingga merangsang pikiran, perasaan, perhatian dan minat serta kemauan peserta didik sedemikian rupa sehingga proses belajar terjadi dalam rangka mencapai tujuan pembelajaran secara efektif'.

Kokom Komulasari, mengemukakan "media pembelajaran pada dasarnya merupakan bentuk pembelajaran yang tergambar dari awal sampai akhir yang disajikan secara khas oleh guru. Dengan kata lain, model pembelajaran merupakan bungkus atau bingkai dari penerapan suatu pendekatan, metode, dan teknik pembelajaran." Menurut Agus Suprijono, "model pembelajaran dapat didefinisikan sebagai kerangka konseptual yang melukiskan prosedur sistematis dalam mengorganisasikan pengalaman belajar untuk mencapai tujuan belajar."

Agus Suprijono, berpendapat bahwa "media pembelajaran adalah suatu rencana atau pola yang dapat digunakan untuk membentuk kurikulum (rencana pembelajaran jangka panjang), merancang bahan-bahan pembelajaran, dan 
membimbing pembelajaran di kelas."

Menurut Rusman, media pembelajaran memiliki ciri-ciri sebagai berikut :

a. Berdasarkan teori pendidikan dan teori belajar dari para ahli tertentu. Media ini dirancang untuk melatih partisipasi dalam kelompok secara demokratis.

b. Mempunyai misi atau tujuan pendidikan tertentu, misalnya media berpikir induktif dirancang untuk mengembangkan proses berpikir induktif.

c. Dapat dijadikan pedoman untuk perbaikan kegiatan belajar mengajar di kelas, misalnya model synectic dirancang untuk memperbaiki kreativitas dalam pelajaran mengarang.

d. Memiliki bagian-bagia media yang dinamakan: (1) urutan langkah- langkah pembelajaran, (2) adanya prinsip-prinsip reaksi, (3) sistem sosial, dan (4) sistem pendukung. Keempat bagian tersebut merupakan pedoman praktis bila guru akan melaksanakan suatu model pembelajaran.

e. Memiliki dampak sebagai akibat terapan media pembelajaran. Dampak tersebut meliputi: (1) dampak pembelajaran, yaitu hasil belajar yang dapat diukur, (2) dampak pengiring, yaitu hasil belajar jangka panjang.

f. Membuat persiapan mengajar (desain intruksional) dengan pedoman model pembelajaran yang dipilihnya.

\section{Media Gambar}

Diantara media pembelajaran, media gambar adalah media yang paling umum dipakai. Hal ini dikarenakan siswa lebih menyukai media gambar daripada tuisan, apalgi gambarnya dibuat atau disajikan sesuai dengan persyaratan gambar yang baik, sudah barang tentu akan menambah semangat siswa dalam mengikuti proses pembelajaran.

Menurut Hamalik media gambar adalah segala sesuatu yang diwujudkan secara visual kedalam bentuk dua dimensi sebagai curahan atau pikiran yang bentuknya bermacam-macam seperti lukisan, potret, siled, film,strip, opaque proyektor . Menurut Soelarko media gambar adalah media yang paling umum dipakai yang merupakan bahasa umum yang dapat dimengerti dan dinikmati, dan merupakan peniruan dari benda-benda dana pemandangan dalam hal bentuk, rupa, serta ukurannya relaif terhadap lingkungannya .

Dari pengertian diatas dapat disimpulkan bahwa media gambar adalah perwujudan lambing dari hasil peniruan-peniruan benda-benda, pemandangan, curahan piker atau ide ide yang divisualisasikan kedalam bentuk dua dimensi. Bentuknya dapat berupa gambar situasi dan lukisan yang berhubungan dengan pokok bahasan hitung.

\section{Manfaat Media Gambar}

Media pembelajaran khususnya media visual(media gambar) dapat mempertinggi proses belajar peserta didik dalam pengajarannya. Media gambar diharapkan dapat mempertiggi prestasi belajar yang dicapainya, ada beberapa alasan mengapa media pendidikan dapat mempertinggi prestasi belajar peserta didik.Menurut Arsyad, "Media pembelajaran memiliki 4 fungsi, fungsi dari media pembelajaran 
khususnya media berbasis visual yaitu antara lain: (1) fungsi atensi; (2) fungsi afektif; (3) fungsi kognitif; serta (4) fungsi kompensantoris. Fungsi atensi mengarah pada konsentrasi siswa agar fokus pada pembelajaran. Fungsi afektif yaitu untuk memancing sikap serta emosi yang dimiliki oleh siswa terhadap media pembelajaran yang ditampilkan. Fungsi kognitif untuk mempermudah proses mencapai tujuan pembelajaran yang telah ditentukan. Siswa akan lebih mudah mengingat dan memahami informasi yang ditunjukkan dari media yang digunakan. Sedangkan fungsi kompensantoris yaitu untuk mendorong siswa yang lambat dan lemah dalam menerima informasi yang disampaikan secara verbal".

Berdasarkan pendapat diatas dapat diambil kesimpulan bahwa media pembelajaran memiliki beberapa manfaat antara lain yaitu menciptakan suasana pembelajaran yang dapat menumbuhkan konsentrasi siswa, lebih menarik, dan dapat berjalan dengan efektif sehingga mempermudah proses mencapai tujuan pembelajaran yang telah ditentukan.

\section{METODE PENELITIAN}

Penelitian ini dilaksanakan di SMK YPIS Maju beralamat di jalan Tengku Hamir Hamzah Km.26,5 No 638 Jati Karya Kecamatan Binjai Utara Kota Binjai. Rencana pelaksanaan penelitian di semester ganjil tahun pelajaran 2019/2020. Setiap penelitian tidak lepas dari wilayah dan daerah tertentu sebagai sasaran penelitian. Hasil penelitian harus dapat menjelaskan sekumpulan objek yang lengkap secara keseluruhan. Keseluruhan dari sifat-sifat tertentu disebut populasi.

Menurut Arikunto bahwa "Populasi adalah keseluruhan subjek penelitian". Populasi dalam penelitian ini adalah seluruh siswa kelas X SMK Swasta YPIS Maju Binjai Tahun pelajaran 2019/2020. Dengan jumlah keseluruhan 108 orang siswa yang terdiri dari 5 kelas, X.RPL 33 Siswa, X.TBSM 21 siswa, X.AKL 10 siswa, X.OTKP 16 siswa, X.TKJ 28 Siswa. Adapun yang menjadi sampel dalam penelitian ini adalah Kelas X TBSM yang berjumlah 21 siswa.

Desain dengan modal ini memberikan perlakuan yang sama pada setiap subjek memperlihatkan dasar kemampuan yang dimiliki. Meskipun terdapat kemungkinan masing-masing pada subjek sampel memiliki kemampuan dasar yang sangat berbedabeda. Kesimpulannya, siswa yang menjadi sampel dalam penelitian ini akan mendapatkan hal yang sama pula yaitu perlakuan dengan memperoleh kemampuan menulis tek anekdot.

Data-data hasil penelitian secara kuantitatif deskriptif adalah menganalisis data-data yang telah terdapat dalam tabletabel data. Arikunto menyatakan bahwa, analisis kuantitatif deskriptif adalah statistic yang digunakan untuk mengipsikan atau menggambarkan data yang telah terkumpul sebagaimana adanya tanpa membuat kesimpulan yang berlaku untuk umum atau generalisasi”. Adapun langkah-langkah dalam menganalisis data tersebut yaitu: Mentabulasi skor yangg dicapai oleh siswa, caranya dengan membuat table dan menstabulasi skor nilai evaluasi siswa pada kemampuan menulis teks anekdot dengan 
menggunakan media gambar, Menghitung rata-rata hasil siswa.

\section{HASIL PENELITIAN DAN PEMBAHASAN}

Penilaian tersebut terdiri dari 5 kreteria penilaian meliputi skor penilaian yaitu

1. Isi yaitu : Jika 80-100 \% judul dan isi teks anekdot sesuai dengan tema skror 20 , Jika $60-80 \%$ judul dan isi teks anekdot sesuai dengan tema skor 15 , Jika 40-60 \% judul dan isi teks anekdot sesuai dengan tema skor 10. Hanya memuat tiga struktur teks anekdot dari lima yang ada (misalnya hanya memuat abstraksi, orientasi, dan krisis skor 5.

2. Struktur teks yaitu memuat kelima struktur teks anekdot yaitu abstraksi, orientasi, krisis, reaksi dan koda skor 20, Hanya memuat empat struktur teks anekdot dari lima yang ada (misalnya hanya memuat abstraksi, orientasi, krisis, dan reaksi dengan skor 15, Hanya memuat tiga struktur teks anekdot dari lima yang ada (misalnya hanya memuat abstraksi, orientasi, dan krisis) skor 10, Hanya memuat dua struktur teks anekdot dari lima yang ada (misalnya hanya memuat abstraksi dan koda) skor 5.

3. Kosa Kata yaitu Penguasaan kata canggih; pilihan kata dan ungkapan efektif; menguasai pembentukan kata; penggunaan register tepat skor 20, Penguasaan kata memadai; pilihan, bentuk, dan penggunaan kata atau ungkapan kadangkadang salah tetapi tidak mengganngu skor 15, Penguasaan kata terbatas; sering terjadi kesalahan bentuk, pilihan, dan penggunaan kosakata atau ungkapan; makna membingungkan atau tidak jelas skor 10,
Penguasaan kata terbatas; sering terjadi kesalahan bentuk, pilihan, dan penggunaan kosakata atau ungkapan; makna membingungkan atau tidak jelas skor 5

4. Kalimat yaitu Konstruksi kompleks dan efektif; terdapat hanya sedikit kesalahan penggunaan bahasa (urutan ataufungsi kata, artikel, pronominal, preposisi) skor 20, Konstruksi sederhana tetapi efektif; terdapat kesalahan kecil pada konstruksi kompleks; terjadi sejumlah kesalahan penggunaan bahasa (fungsi atau urutan kata, artikel, pronomina, preposisi) tetapi makna cukup jelas skor 15, Terjadi kesalahan serius dalam konstruksi kalimat tunggal atau kompleks (sering terjadi kesalahan pada kalimat negasi, urutan atau fungsi kata, artikel, pronomina, kalimat fragmen, pelesapan; makna membingungkan atau kabur skor 10, Tidak menguasai tata kalimat; terdapat banyak kesalahan; tidak komunikatif; tidak layak nilai skor 5 .

5. Kelengkapan Jika 80-100 \% menggunakan EYD dengan benar (penggunaan tanda baca dan huruf kapital) skor 20, Jika 60-80\% menggunakan EYD dengan benar (penggunaan tanda baca dan huruf kapital) skor 15, Jika 40-60 \% menggunakan EYD dengan benar (penggunaan tanda baca dan huruf kapital) skor 10, Jika < 40\% menggunakan EYD dengan benar (penggunaan tanda baca dan huruf kapital) skor 5 .

Berdasarkan perhitungan diatas maka diketahui tingkat kemampuan menulis teks anekdot dengan menggunakan media gambar dari perhitungan rata rata nilai yang diperoleh siswa menunjukkan rata rata yang dipeoleh adalah 1725 dengan rata rata 82.14 dengan kategori cukup. Siswa yang 
memperoleh nilai sangat baik 92-100 berjumlah 1 orang siswa dengan persentase $4,77 \%$. Siswa yang memperoleh nilai baik 83-92 berjumlah 11 siswa dengan persentase $52,38 \%$.Siswa yang memperoleh Cukup 75-83 berjumlah 7 siswa dengan persentase 33 ,33 \% Siswa yang memperoleh nilai kurang 75 berjumlah 2 siswa dengan persentase 9,52 $\%$.

Berdasarkan pembahasan di atas dapat dilihat bahwa kemampuan sisiwa dalam menulis teks anekdot dengan mengunakan gambar adalah dengan kategori baik dengan nilai rata rata 82.14. Hal ini dapat dilihat dari

1. Dari perhitungan rata rata nilai yang diperoleh siswa menunjukkan rata rata yang dipeoleh adalah 82,14

2. Siswa yang memperoleh nilai sangat baik 92-100 berjumlah 1 siswa dengan persentase $4,77 \%$

3. Siswa yang memperoleh nilai baik 83-92 berjumlah 11 siswa dengan persentase 52,38\%

4. Siswa yang memperoleh nilai cukup 75-83 berjumlah 7 siswa dengan persentase $33.33 \%$

5. Siswa yang memperoleh nilai kurang dari 75 berjumlah 2 siswa dengan persentase $9,52 \%$

Dengan mengetahui hasil pengolahan data dalam menentukan kemampuan siswa dalam menulis teks anekdot oleh siswa kelas X TBSM dengan menggunakan media gambar tahun pembelajaran 2019/2020 dengan kategori cukup dengan nilai rata rata 82, 14

\section{PENUTUP}

Dari hasil pengumpulan data, pengolahan data dan penganalisisan data serta pembahasan hasil penelitian adalah sebagai berikut:

1. Dari perhitungan rata rata nilai yang diperoleh siswa menunjukkan rata rata yang dipeoleh adalah 82,14

2. Siswa yang memperoleh nilai sangat baik 92-100 berjumlah 1 siswa dengan persentase $4,77 \%$

3. Siswa yang memperoleh nilai baik 83-92 berjumlah 11 siswa dengan persentase $52,38 \%$

4. Siswa yang memperoleh nilai cukup 75-83 berjumlah 7 siswa dengan persentase $33.33 \%$

5. Siswa yang memperoleh nilai kurang dari 75 berjumlah 2 siswa dengan persentase $9,52 \%$

\section{DAFTAR PUSTAKA}

Agus Suprijono.2010.Cooperative Learning Teori \& Aplikasinya.Yogyakarta: Pustaka Pelajar.

Arikunto, suharsimi.2003.Prosedur penelitian suatu pendekatan praktik.Jakarta: PT Rineka Cipta.

Darmadi Kaswan. 1996. Meningkatkan Kemampuan Menulis. Yogyakarta: Andi.

Djuhari Suherli.2005. Panduan Membuat Karya Tulis. Bandung: CV Yrama Widya. 
Enre. 1998. Dasar-dasar Keterampilan

Menulis.Jakarta: Depdikbud

Hamalik.1994.Media Gambar Dalam

Pembelajaran. Surabaya: Perwira Press

Imron Rosidi. 2009.Menulis Siapa

Takut. Yogyakarta:Kanisius.

Kokom Komulasari.010. Pembelajaran Kontekstual Konsep dan Aplikasi.Bandung: PT. Refika Aditama

Nurgiyantoro.2012 Penilaian Pembelajaran Bahasa.Yogyakarta: BPFE

Nurudin. 2010. Dasar-Dasar Penulisan. Malang: UMM Press

Miftahul Huda.2013. Model-model Pengajaran dan Pembelajaran.Yogyakarta: Pustaka Pelajar.

M. Subana, dan Sunarti.2011.Strategi Belajar Mengajar Bahasa Indonesia. Bandung: Pustaka Setia.

Rusman. 2011. Model-model Pembelajaran. Jakarta: PT Raja Grafindo Persada.

Syahafandi Murdany M, ( 2014) "menentukan gagasan utama dan gagasan penjelas dalam paragrap"(Skripsi Sarjana ), Hal. 20.
Soeparno.1998. Media Pengajaran Bahasa. Yohyakarta: PT Intan Pariwara

Soerlarko.1994.Media Pembelajran . Bandung: UPI Press

Sugiyono, 2008. Metode Penelitian Pendidikan. Bandung : Alfabeta.

Suherli, M.Pd, 2010. Menulis Karangan Ilmiah. Sukamaju Depok : Arya Duta.

Sayuti Suminto. 2000. Berkenalan dengan Prosa Fiksi. Yogyakarta: Gama Media

Sutarno N. S. 2008. Menulis yang Efektif. Jakarta: Sagung Seto.

Tarigan,H.Guntur.1986. Menulis Sebagai Suatu Ketrampilan Berbahasa. Bandung:Angkasa

The Liang Gie. Terampil Mengarang. (Yogyakarta: PT Andi, 2002), hlm 3

Wulandari Setyaningrum.2013. Rangkuman Materi Bahasa Indonesia SMP/MTS Kelas VII, VIII, \& IX.Jogjakarta: Javalitera.

Widyamartaya, Al dan Veronica Sudiati.1997. Dasar-Dasar Menulis Karya Ilmiah. Jakarta: Grasindo 